\title{
KÜRESELLEŞME VE ÇAĞDAŞ SANAT
}

\section{Atiye GÜNER * İsmail Erim GÜLAÇTI **}

\section{Öz}

$\mathrm{Bu}$ çalışmanın amacı çağdaş sanatın, küreselleşmenin önemli bir dinamiği olduğunu ortaya koymaktır. Küreselleşme olgusunun sanatla ilişkisi sorgulanmış, çağdaş sanat; sanatçı, küratör, çağdaş sanat fuarları ve bienaller, küreselleşme olgusu üzerinden incelenmiştir. Küreselleşme ekonomik, siyasi ve sosyo-kültürel alanlarda bütüncül bir yapıya sahiptir. Küreselleşme ekonomik, politik ve sosyokültürel yapıların biraraya gelmesi ve yeni iletişim teknolojilerinin küresel kullanımıyla oluşur (Erdoğan, 2013, 76). Küreselleşmenin homojenleşme, kutuplaşma, hibritleşme gibi kültürel getirileri sanata yeni bir kimlik kazandırmıştır. Çağdaş sanat diye tanımlanan bu yeni kimlik; disiplinlerarası, çok kültürlülük özelliği taşıyan, zaman, mekan kavramından bağımsız, anlatım ve plastik dil açısından çok çeşitlilik içeren bir yapıya sahiptir. Sanat, toplumun kendini ifade etmesini sağlayan kültürel bir güçtür. Günümüzde kültürün iletenleri olarak dijital teknoloji ve medya, çağdaş sanatın en önemli belirleyenleridir. Çağdaş sanat, iletişim teknolojilerindeki gelişme ile hız faktörünü kazanarak zaman ve mekandan bağımsızlaşmıştır. Ekonomik sistemle bütüncül bir yapı oluşturmakta, yaşamın içinde yer almakta ve küreselleşmenin kültürel boyutunun büyük bir bölümünü oluşturmaktadır.

Anahtar Kelimeler: Küreselleşme, Küreselleşmenin Boyutları, Çağdaş Sanat, Kültür Endüstrisi, Küratör

* Öğr. Görevlisi, Hasan Kalyoncu Üniversitesi İletişim Fakültesi Görsel iletişim Tasarımı Bölümü, e-mail: atiye.guner@hku.edu.tr

** Dr. Öğr. Üyesi, Yıldız Teknik Üniversitesi, Sanat Tasarım Fakültesi, e-mail: egulacti@yildiz.edu.tr 


\title{
Globalization and Contemporary Art
}

\begin{abstract}
Abstarct
Purpose of the study is to provide evidence for the fact that contemporary art is an important dynamism of globalization. The relationship between globalization and art was examined and contemporary art, artists, curators, contemporary art fairs and biennials have been studied through the phenomenon of globalization. Globalization; economic, political, socio-cultural areas have a holistic structure. Globalization occurs with a combination of these structures and the global use of new communication technologies (Erdoğan, 2013, 76). The cultural connotations of globalization, such as homogenization, polarization, and hybridization, have given a new identity to art. This new identity, defined as contemporary art, has a multidisciplinary structure that is independent of time, space and diverse in terms of expression and plastic language. Art is a cultural power that allows people to express themselves. Digital technology and media are important determinants of contemporary art. Contemporary art has become independent of time and space by acquiring the speed with the development of communication technologies, forms an integrated structure with economic system, takes part in life and forms a large part of the cultural dimension of globalization.
\end{abstract}

Keywords: Globalization, Dimensions of Globalization, Contemporary art, Culture industry, Curator

\section{Giriş}

Küreselleşme; uluslararası, ekonomik, sosyo-kültürel, siyasal ve politik ilişkilerin, ileri iletişim teknolojileri ile hızlanarak artması ile dünyanın ekonomik, teknolojik, siyasi ve kültürel alanlarda tek büyük bir pazara dönüşme sürecidir. Küresel (global) sözcüğünün kökeni 400 yıl öncesine gitse de küreselleşme (globalization) kavram ve olgu olarak daha yenidir. İlk kullanıldığı 1950'lerin sonundan bugüne kompleks ve tartışmalı bir kavram olan küreselleşme kavramı için, giderek genişleyen literatür henüz bir tanım konusunda uzlaşmış değildir (Çelik, 2012, 57-58). Uluslararası, siyasi, teknolojik, ekonomik ve sosyo-kültürel alanlarda görülen küreselleşme olgusu, daha çok ekonomik boyutuyla incelenmiştir. Ancak küreselleşme 
üzerine artarak yapılan çalışmalarla küreselleşmenin sadece ekonomik bir olgu değil, toplumsal yaşamın birçok ayrıntısını içeren bir oluşum olduğu anlaşılmaya başlanmıştır (Günsoy, 2006, 3). Küreselleşmeye dair tanımların birçoğunda varolan "çokulusluluk", mal ve hizmetin uluslarası dolaşımını sağlayan "serbest piyasa" faktörü, iletişim sektöründeki hızlı gelişme ile oluşan "hız" faktörü ve tüketim anlayışında oluşan değişiklikler ekonomik açıdan tektipleşmeye gidilmesine neden olduğu gibi kültürel bir entegrasyon süreci başlatmıştır. Kültürel entegrasyon, bilişim, iletişim teknolojileri ve medyanın yarattığı güçlü iletişim ile daha da hızlanmaktadır. Yaşanan süreç sanatı daha hareketli (mobilize), güçlü etkileşim platformları yaratan disiplinlerarası bir yapıya dönüştürmektedir.

\section{Küreselleşme Üzerine Görüşler}

Julian Stallabrass "Küreselleşmenin Parçalanışı ve Çağdaş Sanatın Açmazları" isimli makalesinde küreselleşmeyi paranın, yatırımın ve metaların daha serbest dolaşımı ve bu özgürlüğü düzenleyen hukuki anlaşmalar ve eşitlikçi olmayan uluslarası ticaretin yarattığı sonuçlar bağlamında düşünmek gerektiğini söyler (Stallabrass, 2013). Peter Dicken'e göre küreselleşme uluslararasılaşmadan daha ileri ve kompleks bir kavram olup mal ve hizmet akımlarının ülke ve bölge sınırları içinde artmasını sağlayan ve ekonomik faaliyetlerin uluslararası alanda dağılımını arttırmak suretiyle ulusların fonksiyonel entegrasyonunu sağlayan bir olgudur (Çelik, 2012, 59). Harris, küreselleşmeyi "mal ve hizmetlerin üretiminin, dağılımının ve pazarlamasının uluslarasılaştırılmasının artmasıdır" diye tanımlar (Harris, 1993, 1). Ersoy’a göre günümüzde küreselleşmenin mahiyetini, sınırlarını belirleyen ona yön ve biçim kazandıran esas unsur batı kaynaklı kapitalizmdir. Kapitalizmin genelinde dünya geneline hakim olmak ve onu bağımlılık ilişkileri dahilinde adeta tek pazar arzusu ve stratejisi haline getirmek vardır (Ersoy, 2008, 143). Üretim faktörlerini belli bir güç altında toplama 
isteği toplumların politik ilişkilerinin artmasına neden olmuştur. Uluslarası ilişkilerin artışı insanlıkla ilgili temel ilkelerin saptanmasında yol gösterici olan kültürel ilişkilerin hızlanmasına neden olmuştur. Roland Robertson küreselleşmeyi şöyle tanımlar: "Küreselleşme dünyanm kontrol altına alınmasını ve tek bir bütün olduğunun farkına varılmasını ifade etmektedir. Ayrıca dünya üzerinde yaşayan insanların birbirlerine olan bağımlılıkları ile ilgili bilinç de hızla artmaktadır" (Robertson. 1992, 8).

McLuhan 1962 yılında yazdığı “Gutenberg Galaxy” isimli kitapta "The Global Village” betimlemesiyle dünyayı büyük bir küresel köye benzetmiştir. İletişim teknolojisindeki hızlı gelişmeler, kolektif kabile bilincini yeniden canlandırmakta, dünya her an herkesin birbiri ile etkileşimde bulunabileceği küresel bir köye dönüşmektedir. McLuhan küreselleşme bağlamında düşünürleri etkileyen üç önemli durumdan bahsetmiştir. İletişim araçlarında elektriğin kullanılışı, insanın sinir sistemine benzeyen bir haberleşme ağı yaratmakta; bu haberleşme ağı sayesinde dünyanın bir bütün olarak algılanması mümkün olmaktadır. Gece ve gündüz eşit aralıklarla 24 saat çalan mekanik saatlerin tüm dünyada kullanılışı, zamanın mekandan bağımsızlaşmasına, modernizasyonu yayan ticaret ve sanayinin gelişimine yol açan devrimsel bir olaydır. Üçüncü olarak paranın alışverişlerde ödeme aracı olarak kullanımının yaygınlaşması ekonomik faaliyetlerin hacmini arttırmakta ve hızlandırmaktadır (Eşkinat, 1998, 37-40). McLuhan'ın tespitleri küreselleşme teorisi üzerine çalışmalar yapan düşünürlere katkıda bulunmuştur. Anthony Giddens küreselleşmenin ön koşulunun zamanın mekandan bağımsız kalması olduğunu söylemiştir. Evrensel saatlerin kullanımı ile zaman evrenselleşmiştir. Küresel haritalar mekanın evrensel boyutlarda algılanmasını sağlamıştır. Böylece toplumsal ilişkiler zaman ve mekandan kaynaklanan sınırlamalardan kurtulmuş ve dünya ölçeğinde yeniden yapılanmıştır. Giddens toplumların artan ilişkilerinin ekonomik değil toplumsal, kültürel ve politik alanlarda da etkili olup toplumun yeniden yapılandığını ileri sürmüştür (Çelik, 
2012, 59).

Tanımlarda görüleceği gibi küreselleşmeyi sadece ekonomik değişiklerle açıklayabilmek mümkün değildir. Başlangıç sebebi ekonomik gibi gözükse de küreselleşme olgusu ekonomik, politik ve kültürel alanlarda bütüncül bir yapıya sahiptir. Marcuse, geç kapitalizmin temel özelliğinin bütüncül bir toplum olduğunu bu yapı içerisinde teknoloji, siyaset ya da kültürü kopuk biçimde ifade etmenin olanaksız olduğunu söylemiştir. Marcuse'ye göre çağdaş sanayi toplumu, teknolojik temelini düzenleyiş biçimiyle, iktisaditeknik tektipleşmeyi sağlar ve bu bütüncüllüğü sağlamada en önemli görev kültüre düșer (Dellaloğlu, 2018, 111).

\section{Küreselleşmenin Kültürel Boyutu ve Sanatla İlişkisi}

1960'lardan sonra dünyada yaşanan sorunlar; 1963 Vietnam krizi, 1970’lerde ABD'nin kapitalizm modelindeki sorunlar, ABD'de ve Avrupa'da halk hareketleri, enflasyon ve özellikle petrol krizi neoliberalizmin koşullarını hazırlar. 1960-1980 yılları arasındaki postmodernizm diye adlandırılabilecek geçiş döneminden sonra, İran-Irak savaşının (1980-1988) yaşandığı, Berlin duvarının yıkıldığ (1989), Sovyetler Birliğinin dağıldığl, Çin'in kapitalist ekonomiye geçişi ve Yugoslavya'da iç savaş (1990- 1995) ve ardından dağılmanın yaşandığı dönem ile birlikte Neo-liberalist bir sistem dünyaya hakim olur (Erdoğan, 2013, 79). Çokuluslu şirketlerin ortaya çıktığı, ulus devletlerin yok olmaya başladığı sistemde kültürel entegrasyon kaçınılmazdır. İletişim ve bilişim teknolojilerindeki hızlı gelişme kültürel entegrasyon sürecini hızlandırmış; dünyanın uzak köşelerindeki toplumların bile birbiriyle anında iletişim kurup haberdar olmaları kuvvetli bir etkileşime neden olmuştur. Bir anlamda yeni çokuluslu ekonomik sistem küreselleşmenin kültürel boyutunu çok önemli bir hale sokmuştur.

Kültür dünyayı anlamlandırabilmeyi ve toplumsal kimliklerimizin oluşmasını sağlayan değerler bütünüdür. Sanat ise 
kültürel değerlerin büyük bir bölümünü kapsamaktadır. İnsanlığın doğa karşısında varoluşunu kanıtladığı birbiri ile iletişim kurabildiği önemli bir güç, bir ifade dilidir. Aynı zamanda toplumların birbirlerini etki altına aldığı yollardan birisidir. 20. yüzyılın sonlarına doğru yaşanan küreselleşme ile kültürün ve buna bağlı olarak sanatın ekonomikleștiği, piyasanın isteğine göre şekillendiği görülmektedir. $\mathrm{Bu}$ durumun en iyi göstergesi sanatın reklam sektöründe markalandırmaya yönelik kullanılışıdır. Günümüzde sanat, reklamcılık ve tasarım birbirinden ayırt edilememektedir.

Kültür ve sanatın endüstrileşmesine 1944'de yazdıkları "Aydınlanmanın Diyalektiği" isimli yapitlarıyla Frankfurt okulu düşünürlerinden Adorno ve Horkheimer dikkat çekmişlerdir. Geç kapitalizmin sadece ekonomik ve siyasi yönden açlklanamayacak kadar gelişmiş bir yapıya sahip olduğu üzerinde dururlar. Gelişmiş kapitalizm içinde paranın bir kültür haline dönüştüğünü, kültürün metalaştığını ileri sürerek kültür endüstrisi denilen bir kuram geliştirirler. Kültür endüstrisi, tüketim toplumu, kitle kültürü, popüler kültür gibi kavramlarla kültürün artık alınıp satılabilir, serbest piyasaya tekrar tekrar sürülebilir bir meta oluşundan bahsederler. Kültür endüstrisi sürecini harekete geçiren dinamik, piyasadır. Simgesel biçimler artık bir bütün olarak pazara yönelik olarak üretilirler. Dolayısıyla kültüre damgasını vuran temel güçlü, en geniş satışı yakalamak en çabuk ve çok kara ulaşmak haline gelir. Kültür endüstrisi kavramı sanat için de geçerlidir. Adorno ve Horkheimere göre sanat da metalaşmıștır. Frankfurt Okulu düşünürleri, Kant'ın Yargı Gücünün Eleştirisinde sanat için kullandığı "ereksiz ereklilik" deyişinin sanatın metalaşmasıyla tam tersine çevrildiğini ileri sürerler. Kant Yargı Gücü'nün Eleștirisi'nde belirttiği "ereksiz ereklilik" ilkesi temelinde "özgür sanat" ile "ücret sanat" arasında bir ayrım yapar. "Özgür sanat" kendi dışında hiçbir ereği olmayan sanattır. "Ücret sanat" ise aslında başka bir erek için üretilmiş sanattır. Sanatın kendi dışında hiçbir ereği olmamalıdır. Ancak o zaman sanat özgürdür. Sanat eserlerinin bir meta olarak ileri 
sürülüşü ile Kant'ın kendi dışında hiçbir ereği olmayan sanat olarak nitelediği özgür sanat yerini bir erek için üretilmiş olan ücret sanata devreder. Benjamin'in deyişiyle 'yapıtın halesi' kaybolur, herbiri bir diğerinin aynısı durumuna geçer, metalașır. Burada yeni olan sanatın metalaşması değil özerkliğinden vazgeçip tüketim metaları içinde gururla yerini alışı, kültür endüstrisinin önemli bir dinamiği haline gelişidir (Dellaloğlu, 2018, 106-115).

Ali Artun, Çağdaş Sanat ve Kültüralizm adlı kitabında, Demirperde'nin yıkılıp soğuk savaşın son bulmasını izleyen dönemi "Kültür Tutulması" başlığı altında inceler. 0 dönemde dünyanın bir kültür dönemecine girdiğini; toplumsal, siyasi hayat ve düşüncenin giderek kültüre soğurulduğunu söyler. Yükselen bu kültür furyası modern zamanlardan çağdaş zamanlara dönüşümün bir sonucudur. Modern kültürün bütün insanlığı aynı uygarlık tarihine kurgulayan homojen yapısı küreselleşme ile heterojenleşmiştir, evrensele karşıdır, tikeldir, rölatiftir. Neo-liberalist sistemde kültür ekonomikleştikçe ekonomi de kültürelleşmektedir. Çağdaş toplum, kültürel özgürleşme adına piyasa tarafından yeniden tasarlanmaktadır ve burada en önemli aracı sanat olmaktadır (Artun, 2015, 9-17). Hem kültürel aracı durumuna düşmekte hem de sanatın kendisi nesnelleşmektedir. Kültürün bir anlamlandırma sistemine evrilmesi sanatı daha da güçlendirmektedir. Böylece sanat, 19. yüzyıldaki özerkliği terk ederek çağdaş yaşamın anlamlandırılmasında ve çağdaş öznelerin inşasında işlevselleşir.

Yılmaz, Bourriaud, Şahiner, Antmen, Danto, Sarup, Barrett, Harris, Wilson gibi birçok düşünür ve eleştirmenin görüş birliği ettiği şey, 1960’ların sanata getirilerinin sosyo-kültürel, teknolojik, ekonomik ve politik itkilerle eş zamanlı bir şekilde ortaya çıkıp sanattaki plastik, estetik, felsefi bir kırılmaya yol açtığıdır. Böylece modern sanat yaklaşımlarının yerini birçok farklı malzeme ve tekniğin bir arada olduğu ve dolayısıyla farklı estetik kaygılarla ortaya çıkan çağdaş yaklaşımlara bıraktığı görüşleri ortaya çıkmıştır. 
Çağdaş terimi ise modern sonrası dönemi ifade etmekte olup en geniş anlamıyla postmodern ve güncel oluşumları içermektedir (Onan, 2016, 7-9).

\section{Sanatın Küreselleşen Yapısı: Çağdaş Sanat}

Küreselleşmenin sosyo-kültürel getirileri konusunda üç görüş vardır. Birinci ve yaygın görüş olan homojenleşme, küreselleşme ile toplumların günlük yaşam pratikleri ve kültürlerinin birbirine benzediği görüşüdür. İkincisi kutuplaşmadır ki homojenleşme tezi aynı zamanda kutuplaşmayı da birlikte getirmektedir çünkü kutuplaşma tezine göre bilginin küreselleşmesiyle oluşan teknolojik değişmeler, kültürler arası diyalog için kullanılabileceği gibi ırkçı bir nefret ve etnik ulusalcılığın müdafaası için de kolaylıkla kullanılabilir. Üçüncü ileri sürülen tez de küreselleşmenin çok kültürlülüğü ve çoğulculuğu teşvik edişidir (Holton, 2013, 62-71). Her ne kadar kültürel anlamda benzer bir kültüre evrilmeden söz edilse de toplumların kendi kültürlerinden kopmalarının zorluğu açıktır. Belirli kültürler belki de birbirine benzeyerek var olacaktır. Böylece zamanla birbiri ile birleşerek melez (hibrit) kültürler ortaya çıkacağı düşünülmektedir. Etnik kültürlerin çağdaş sanatta öne çıkarılışı bir anlamda ötekileştirilen kültürlerin gözönüne çıkarılarak aslında ötekileştirenin daha ayrıcalıklı ve üstün olduğu izlenimini vermektedir. Bu da çok kültürlülüğün etnik ayrımcılığı güçlendiren, ırkçılık anlayışına dayalı bir tutum olduğu görüşünü ortaya koymaktadır.

Küreselleşme ile öne çıkan çok kültürlülük, kutuplaşma, hibritleşme görüşleri, çağdaş sanatta öne çıkan yersiz yurtsuzlaşma, eklektisizm, disiplinlerarasılık gibi kavramlarla ifade bulmuştur. Zaman ve mekan anlayışlarının küreselleşmesi, kültür endüstrisi ile sanatın meta olduğu anlayışları ve iletişim teknolojisindeki hız faktörü sanat anlayışında, sanatın sergileme mekanlarında, anlatım dilinde köklü değişikliklere neden olmuştur. 
1990’lardan itibaren dünyada yaşanan olaylar neticesinde özellikle sosyalist rejimin sona ermesi ile birçok farklı kültür özgürleşmiş, bireylerin aidiyetleri belirsizleşmiş, bu durum sanatsal üretimleri de etkilemiştir. Kültürler arasında böylesi bir geçicilik ve kayganlık aynı toplumsal dönemin ürünleri olan sanat yapıtları için de geçerlidir. Bireylerde oluşan çok kültürlü bakış ve algılama, yapıtlara da yansımıştır. Sanat yapıtlarında çok kültürlü bir yapı kurgulanmakta ve farklı kültürlerin öğeleri kullanılmaktadır. Malzeme olarak sanatta çok parçalılık hakim olmaktadır. Sanat yapıtları bienal, trienal gibi geniş çaplı sanat etkinliklerinde bulundukları yerin kültürel değerlerine göre farklı kurgulanabilmektedir. Kökeni sosyolojik olan bir terimle ifade edilirse yersiz yurtsuzlaştırılmaktadır. Eklektisizm çağdaş yapıtları modern yapıtlardan ayıran en önemli kriterdir. Farklı çă̆ ve unsurlardan öğeler bir arada bulunabilmektedir (Onan, 2016, 11-15). Nam June Paik'in, ilkini 1974'de oluşturduğu Budha heykeli ve karşısındaki TV ekranından oluşan video enstalasyonlarında çağdaş sanatın disiplinlerarası yapısı görülmektedir. Geleneksel kültür ile ileri teknoloji bir araya getirilmiş; çağdaş sanatın disiplinlerarası oluşu, malzeme kullanımındaki çok parçalılık ve çok kültürlülük ironik bir biçimde sergilenmiştir (Görsel 1). Gagosian Galeri'de bulunan “Golden Buddha” (2005), 2015'de Honkong Art Basel'de sergilenmiştir. 


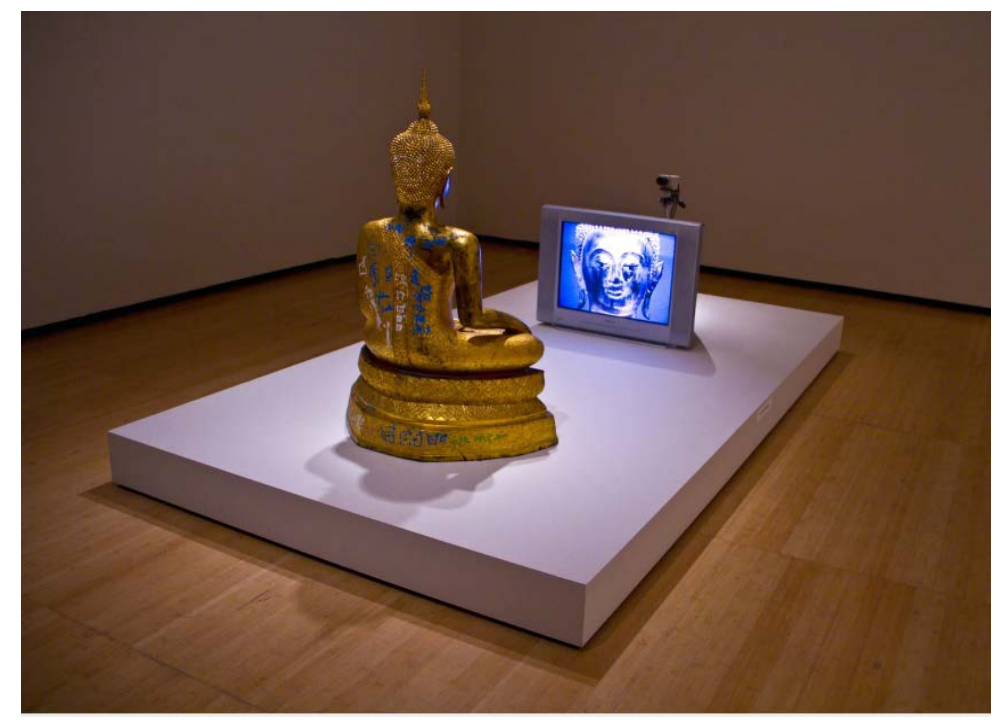

Görsel 1: Golden Buddha, 2005, Video enstalasyon, Gagosian Galeri

Çağdaş sanat dönemi sanatla piyasanın birbirine çok yaklaştığı dönemlerden biridir. Günümüzde medya, reklam ve sanat birbirinin ayrılmaz parçası olarak sanayi kurumu şeklinde çalışmaktadır. Küresel dünya düzeninde sanat, bir yatırım aracı, kültürel bir aracı ve sistemin kendini meşrulaştırma aracı olarak kullanılabilmektedir (Tunçelli, 2014, 69-70). Ali Artun'a göre kültürün ekonomikleşmesi ile sanat önce bir iletişim diline indirgenmekte oradan da şirketlerin kurumsal kültürlerine eklemlenmek üzere yönetim birimlerine soğurulmaktadır. Böylece sanat, başarı kriterleri piyasaya göre belirlenmiş şirkete dönüşmektedir. Avrupa Kültür Vakfı'nın (ECF) yayınladı̆̆ı "Sarsıntılı Zamanlarda Sanat Yönetimi" Kılavuzunda "Kültürel Politikanın Kilit Başlı̆̆ı" altında belirlenen modelde "Sanat ürünü başka herhangi bir üründen farklı değil; dolayısıyla başarısı da ancak piyasadaki başarısıyla ölçülebilir."denmektedir (Artun, 2015, 46-48). Sanat ve yaratıcılı, küreselleşme ile kültürel ekonomiye dahil olmakta, piyasanın yönetiminde işleyen bir finans aracına dönüşmektedir. 
İngiliz sanatçı Damien Hirst'ün Mayfair Galeri'nin vitrinine yerleştirdiği enstalasyon çalışması aynı gece eseri çöp sandığını söyleyen temizlikçi tarafından atılır. Yarı dolu kahve fincanları, sigara izmaritleri ile dolu kül tablaları, boş bira şişeleri, boyalı bir palet, şövale, merdiven, firçalar, şeker ambalajları ve yere yayılmş gazetelerden oluşan eser, Eyestorm Galerisinin sergi açllışı öncesinde düzenlediği V.İ.P galasında tanıttığı sınırlı sayıdaki eserin temel parçasıdır. Temizlik görevlisi yaptığı açıklamada eserin sanat eseri olduğunu anlamayıp çöp sandığını ve attığını belirtir. Sanatın günlük yaşamla ilişkisi üzerinde duran Damien Hirst bu açıklamaya aşırı derecede komik diye tepki verir (Kuspit, 2006, 13-14).
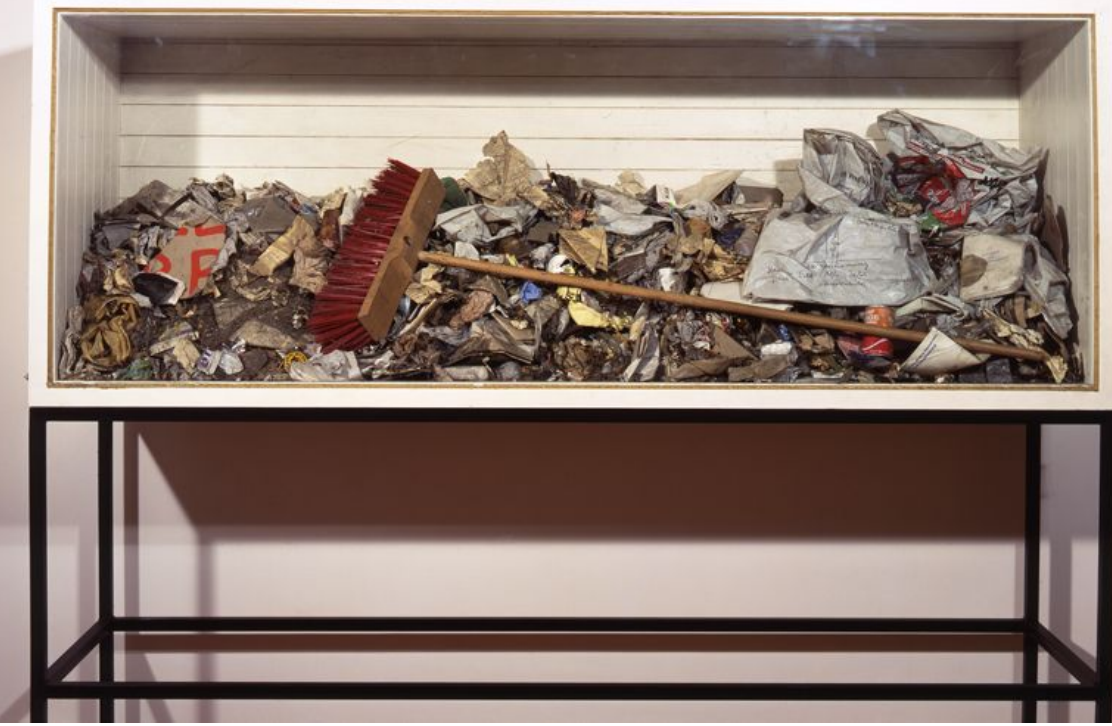

Görsel 2: Joseph Beuys, “Ausfegen” (Süpürüp Atma), 1972-1985, Rene Block Koleksiyonu, Neues Müzesi, Nürnberg

Joseph Beuys, 1 Mayıs 1972'de sosyal eşitliğin herkes için aynı olması gerektiğini savunarak Berlin Karl Marx Meydanında iki öğrencisiyle birlikte, gösterilerden sonra süpürme eylemi yapar 
(Battinelli, t.s ). Süpürge ve süprüntüler galeride sergilenir (Görsel 1). Joseph Beuys'un enstalasyonunda gündelik yaşama ait nesneler göstergeye dönüşmüştür. Çağdaş sanatın görsel bir temsil ortamına dönüşmesi Kuspit'e göre kültürün küreselleșen dünyada bir anlamlandırma sistemi olarak ortaya çıkışı sanatı güçlendirirken bir yandan da tüm yaşama dahil ederek onu popülerleştirmektedir (Kuspit, 2006, 96). Göstergeler anlamlarından bağımsızlaşmakta çağdaş sanat bir illüzyon ortamına indirgenmektedir. Dil ve nesnenin gündelik araçlar kullanılarak kavramsal çatışma yaratan göstergesel işler yapılması modern sonrası sanatın bir ifade dili olmuş ve bu gündemdeki siyasi konularla da ilişkili olmuştur.

Jeff Koons'un, yanlarında floresan tüpleriyle pleksiglas bir kutuya yerleştilmiş elektrik süpürgelerinin yeraldığı eseri Sotheby's'de satışa sunularak 2,16 milyon dolara satılır (Görsel 2). Müzayede kataloğunda eserin "toplumsal cinsiyet rollerinin yanı sıra tüketimciliği konu edindiği” belirtilmiştir (Thompson, 2012, 42).

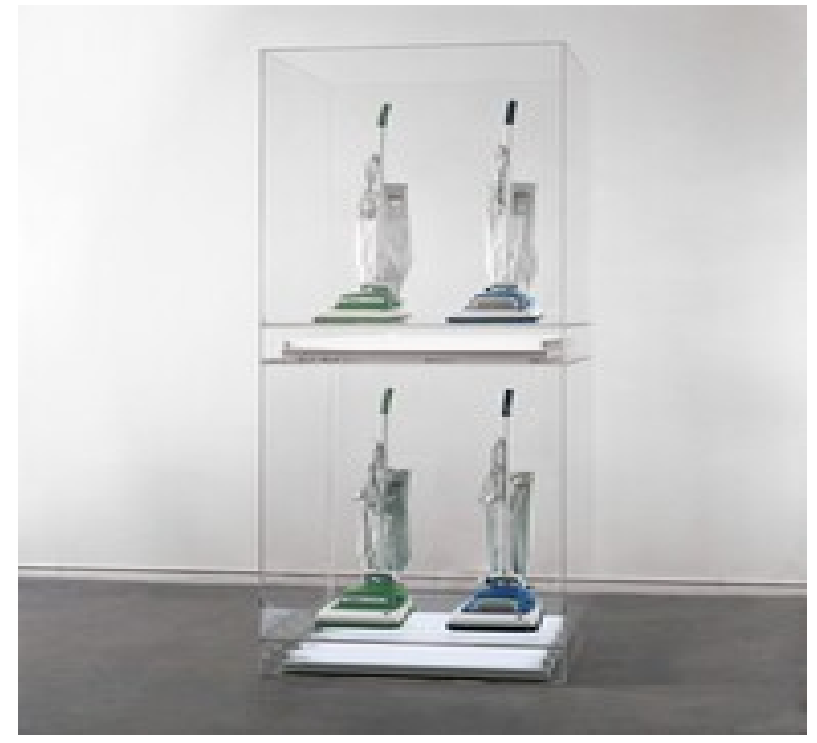

Görsel 3: Jeff Koons, New Hoover Convertibles 
Zaman ve mekandan bağımsız, çağdaş sanat eserlerini belirleyen en önemli belirteç hız faktörü olmuştur. Sanat eserleri hızlıca üretilmekte ve hızlıca tüketilmektedir. Tracey Emin'in "Everyone I Have Ever Slept With 1963-95" isimli eseri doğduğundan bu yana birlikte uyuduğu kişilerin isimlerini işlediği mavi bir çadır enstalasyonudur (Ozgur,2014). Saatchi koleksiyonunda olan eser 1997'de Saatchi koleksiyonundan derlenen Sensation Sergisinde sergilenir. 2004 yılında, bulunduğu sanat deposunda çıkan yangında yok olur (Görsel 3).

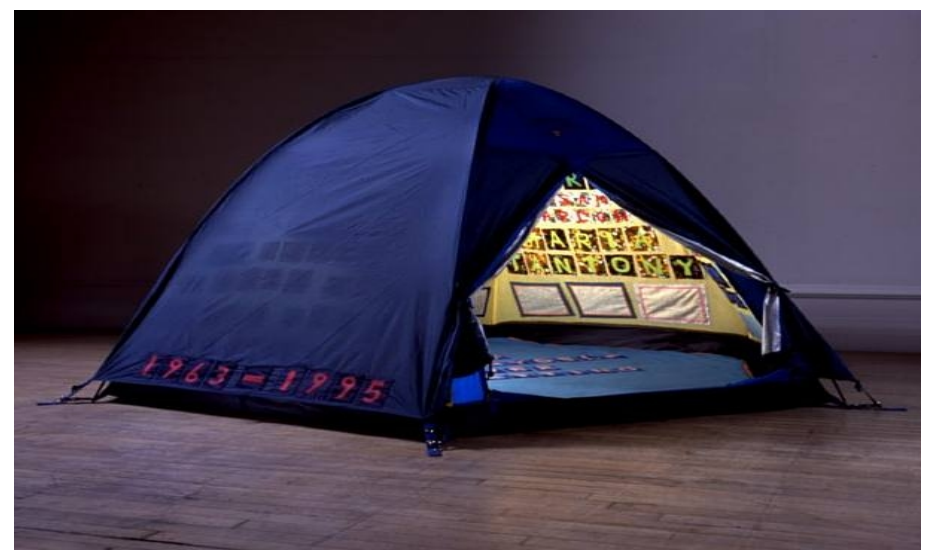

Görsel 4: Tracey Emin, Everyone I have Ever Slept With 1963-95

Tracey Emin'in cinsellik, depresyon, ölüm gibi temaları işlediği kendi yatağı ve dağınık objelerden oluşan “My Bed” Enstalasyonu 1999'da Tate Modern'de sergilenir (Baransel, 2011). Bir Alman sanayici tarafından 3.8 milyon dolara satın alınan eser 10 yıllığına kiralandığı Tate Modern'de 2015'de tekrar sergilenir (Görsel 4). 


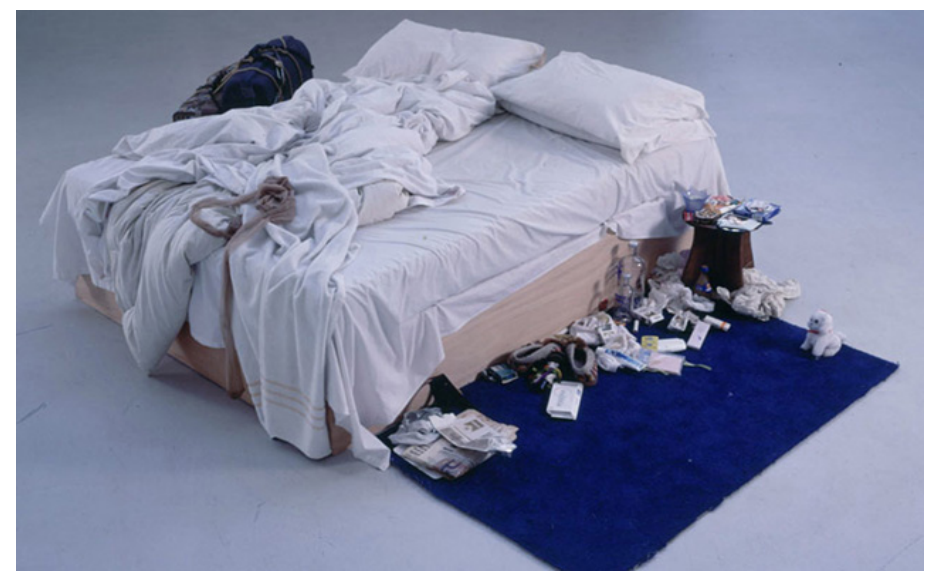

\section{Görsel 5:Tracey Emin, My Bed,1999}

Sanat dili çağın teknolojik olanakları ile enstalasyon, medya sanatı veya dijital sanatın ağırlıkta olduğu bir görünüm kazanmaya başlamıştır (Görsel 5,6).

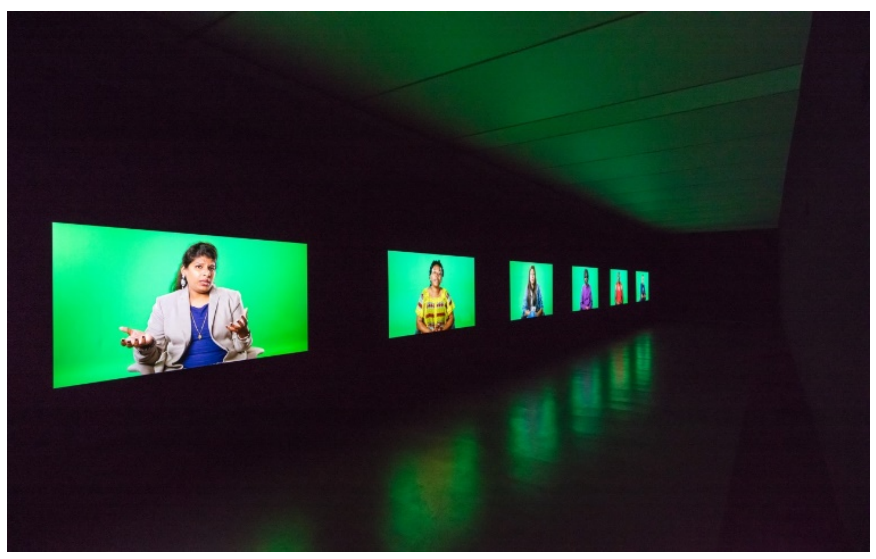

Görsel 6: Candice Breitz, Love Story, Video Enstalasyon, 2016 


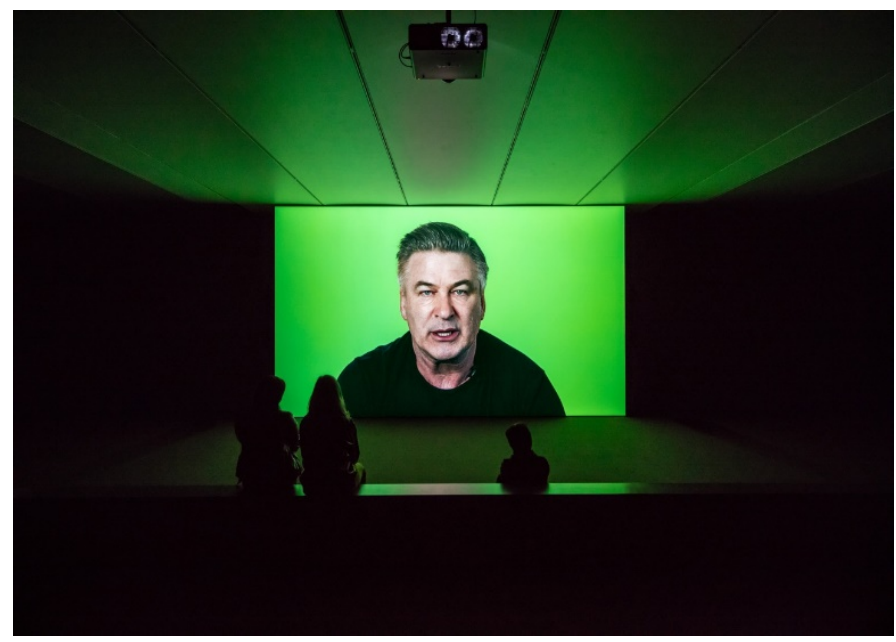

Görsel 7: Candice Breitz, Love Story, Video Enstalasyon, 2016

Candice Breitz küresel bir soruna, mülteci sorununa, ülkesini terk eden altı farklı kişi ile röportaj yaptığı "Love Story" video enstalasyonu ile dikkat çekiyor. Video gösterimi iki farklı odada yapılıyor. Kurulumun ilk odasında, bu zorunlu göç hikayeleri, iki sanatçı Alec Baldwin ve Julianne Moore tarafından geniş bir ekrana aktarllyyor. İkinci bir alanda, orijinal görüşme görüntüleri altı monitörde görülüyor, mültecilerin her biri kendi deneyimlerini anlatıyor (Museum of fine arts, 2018). Küresel ölçekli sorunlar dijital teknolojinin tüm imkanları kullanılarak sanata malzeme olmaktadır. Sanat aracılığı ile küresel sorunlara duyarlılık geliştirilmekte olduğu ve çağdaş sanatın küreselleşme ile çok sıkı bir ilişki içinde olduğu gözlemlenmektedir. 
Çağdaş sanat siyasetle çok yakından ilişkilidir. Çağdaş sanatsiyaset ilişkisi protest sanat, aktivist sanat başlıkları altında incelenebilir. Sanatçı, siyasi veya küresel sorunu, grafiti, sokak sanatı, yerleştirme, performans sanatı gibi disiplinlerarası alanlarda mesaja dönüştürür. Gerçek kimliği bilinmeyen, dünyanın birçok yerinde yaptığı grafitilerle protest ve aktivist tavır sergileyen Britanya'lı sanatçı Banksy, İsrail'in Filistinle arasına ördüğü Batı Şeria duvarının tam karşısında bir otel satın alır. "Walled off Hotel" adını verdiği ve bazı duvarlarında resimlerinin bulunduğu otel Filistin-İsrail sorununa dikkat çeker. Banksy'nin Kudüs'te bir garaj yanındaki duvara stensil ve sprey boyalarla yaptığı "The Flower Thrower" ikonik bir duvar resmidir. Banksy'nin kendi kitabı Wall and Piece'in kapağıdır.

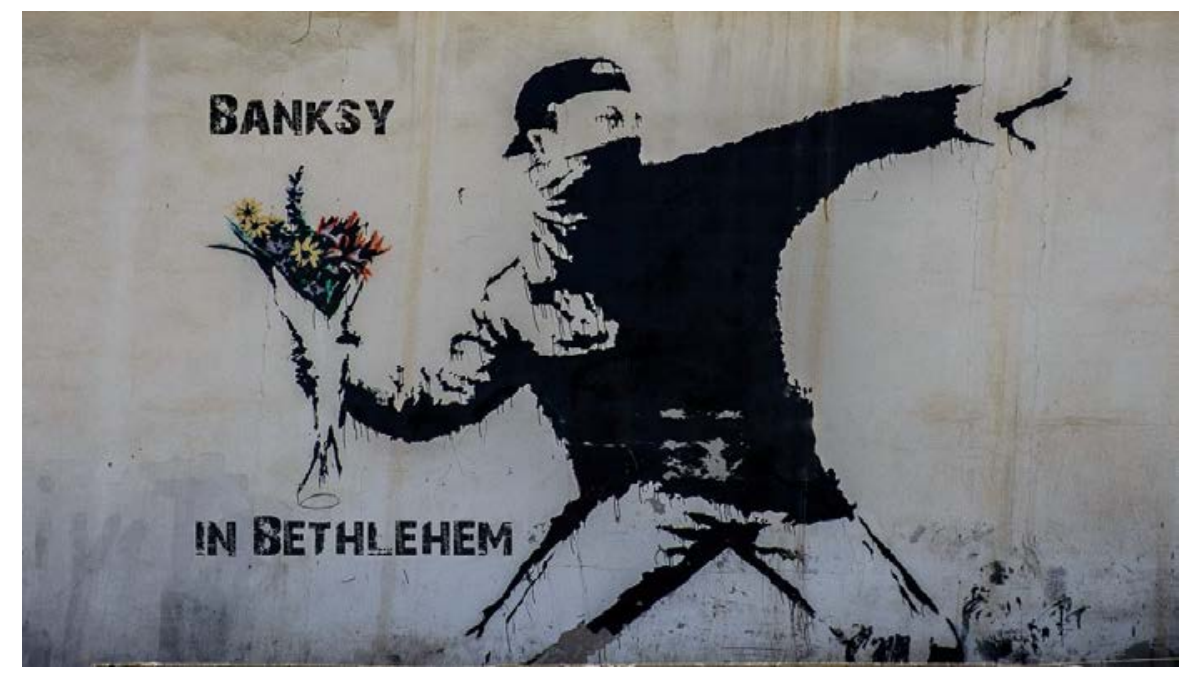

Görsel 8: Banksy, The Flower Thrower, 2005

\section{Çağdaş Sanatçı}

Sanat anlayışındaki, uygulama ve sergileme boyutundaki değişimler sanatçı kimliğinin de değişimine yol açmıştır. $\mathrm{Bu}$ değişimle sanatçı sadece sanatsal becerilerini izleyiciye sunmaya çalışan ve tinsel aura yaratan biri değildir. Neo-liberalist ekonomik 
sisteme ayak uydurarak markalaşmaya doğru giden bir süreç izlemeye başlar. Bu süreçte sanatçının kendini diğer disiplinlerden beslemesi ve felsefe, sosyoloji, teknoloji, ekoloji, müzik, edebiyat, matematik ya da daha birçok farklı disiplinin bilgisiyle etkileşime girmesi gerekmektedir. Malzeme ve teknik açıdan da sınırları zorlamak durumundadır. Böylece sanat yapıtı da kolektif bir bilincin ürününe dönüşür (Onan, 2016, 19-20). Donald Kuspit modern sonrası sanatın en büyük sorununu izleyicinin sanata yatırım yapacak bir müşteri olmasında görür. Kuspit'e göre post sanatçı ise izleyicinin kafasını karıștırarak, gerekirse kendi reklamını yaparak piyasanın hareketliliğini sağlayan baş aktördür. Marjinal yaşamı ve söylemleri ile Andy Warholl yeni sanatçı tipinin önemli bir göstergesidir. Julian Schnabel ise kendisinin “Picasso'dan sonra gelmiş geçmiş en büyük lanet olası sanatçı olduğunu" beyan etmiştir ve Kuspit'e göre bu söylem onun satışını arttırmıştır (Kuspit, 2006).

"Marka bir isim olmak hayatın önemli bir parçası, içinde yaşadığımız dünya bu" diyen sanatçı Damien Hirst'ün, Saatchi tarafından finanse edilen "The Physical Impossibility of Death in the Mind of Someone Living" (Yaşayan Birinin Zihninde Ölümün Maddi İmkansızlığı) isimli dondurulmuş köpekbalı̆̆ enstalasyonu on iki milyon dolara satılır. Kendisi kadar ismi de büyük sansasyona neden olan eser (Görsel 8) sanatçısı tarafından 2007 yılında yenilenerek New York Metropolitan Müzesinde sergilenir. Don Thompson'a göre bu tekrarla sanat eserinin bir eşinin daha yapılamayacak olduğu varsayımı sanatçının kendisi tarafından çürütülmüş olur (Thompson. 2012, 99-101). 


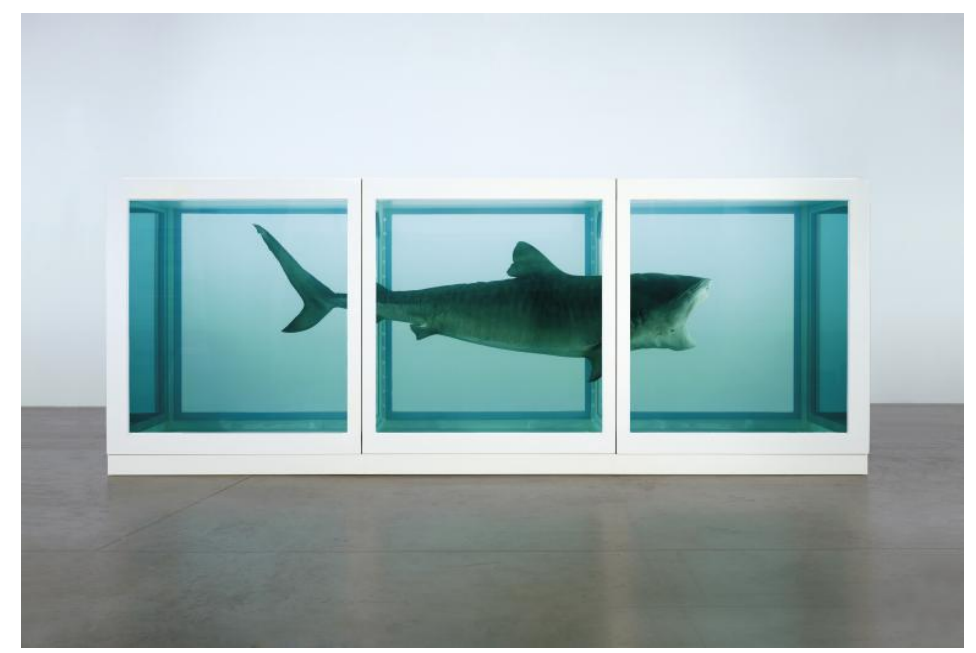

\section{Görsel 9: Damien Hırst, The Physical Impossibility of Death in the Mind of Someone Living, 1991}

Sanatçlar için sanat piyasasında gündemde kalabilmek davranışlardaki farklılıklar ile de olabilmektedir. Sanatçı Haluk Akakçe 2005 Yılında Milliyet gazetesinin başlattığı "Baba Beni Okula Gönder" projesinin 5. yılında kız çocukları yararına düzenlenen on bir farklı daldan sanatçının ve elli altı ressamın yapıtlarından oluşan sergi sonrası düzenlenen müzayedeye katılır. Toplam iki milyon yüz bin TL gelir elde edilen müzayedede Haluk Akakçe, Türkan Şoray’ın "Figürlü Kompozisyon" çalışmasını ikiyüzbin TL'ye alarak dikkatleri üstüne çeker (Aktaş-Deliklitaş, 2010).

Ahu Antmen, "Nasıl 'yaramaz çocuk' halini aldı, kimseyi ilgilendirmez. Bizi esas ilgilendirmesi gereken genç yaşında dünya çapında hatırı sayılır bir sanatsal başarı yakaladıktan sonra Haluk Akakçe'nin kendi ülkesinde kafasına taktığı perukla şöhret olması" diye başladığı yazısında, çağdaş sanatta resim, mimarlık, ışık, ses gibi mecralardan yararlanarak sanat tarihinden popüler dijital kültüre göndermeler yapan görsellerle geleceğin imgesine yönelik vizyonuyla dikkat çeken Haluk Akakçe'nin eğlenmek için kafasına taktığı peruktan sonra bir de Türkan Şoray'ın resmini almasıyla kendi 
ülkesinde şöhret olmasına dikkat çekiyor ve sanat dünyasında şan, şöhrete yönelik olgunun yeni olmadığını söylüyor. Ünlülerin dünyası ile sanatçıların dünyası arasındaki etkileşimi inceleyen İngiliz sanat tarihçi John Walker'a göre Picasso ve Dali'den sonra Andy Warholl, Jeff Koons, Tracey Emin, Jackson Pollock, Jean Michel Basquiat, Damien Hirst, Julian Schnabel, Joseph Beuys'un önde olduğu çağdaş sanatçllar içinde marjinal yaşantılarıyla dikkat çeken olduğu gibi sanatçlların çoğu da medyanın ilgisini kendi çıkarları yönünde bilinçli olarak yürütmektedir (Antmen, 2010).

Sanatçllar küreselleșen dünyada ekonomik sisteme uyum sağlamak ve farklılıklarını ortaya koymak için markalaşma ve kendi şirketlerini kurma yoluna gitmektedirler. Marina Abramovic Newyork'da 1936 Yılında yapılmış bir binayı satın alarak 2013'de kendi adını taşıyan Marina Abramovic Enstitüsüne (MAİ) dönüştürmeye çalışır. OMA tarafından tasarlanacak enstitünün 20 milyon dolarlık bütçesinin bir kısmını toplayabilmek için başlatılan Kickstarter bağış kampanyası için Lady Gaga'nın yer aldığı bir tanıtım filmi çekilir. Birkaç yıl sonra MAİ projesinin maliyeti 31 milyon dolara çıkınca performans sanatı ve farklı disiplinlerden iş birliklerinin gerçekleşeceği yer olarak kullanılması tasarlanan enstitü projesinden vazgeçilir (Sanatatak, 2017). Hudson'da yer alan binayı satma kararı alan Marina Abramovic, "Artık sloganımız: Bize gelmeyin, biz size geliriz" diyerek yaptığı iş için tek bir mekana bağlı olmayacağını söylemektedir. Kickstarter projesi ile Marina Abromovic'e destek olan Lady Gaga, "Abramovic Method" adı verilen performansı gerçekleştirdiği bir video çekti. Videonun başlangıcında entstitüyü marka olarak temsil eden baştan aşağıya beyaz kıyafetler içindeki Lady Gaga, ilerleyen dakikalarda tamamen çıplak bir halde ormanda hareket ederken, nefes alma egzersizleri yaparken ve büyük bir kristale sarılırken görülüyor. Burada kitschin çağdaş sanatta olağanlığı, reklam ve sanatın iç içe geçmiş yapısı görülmektedir. Çarpıcı olan tarafı da Lady Gaga gibi aşırı stil sahibi bir sanatçının tanıtım filmi için seçilişidir (Görsel 9). 


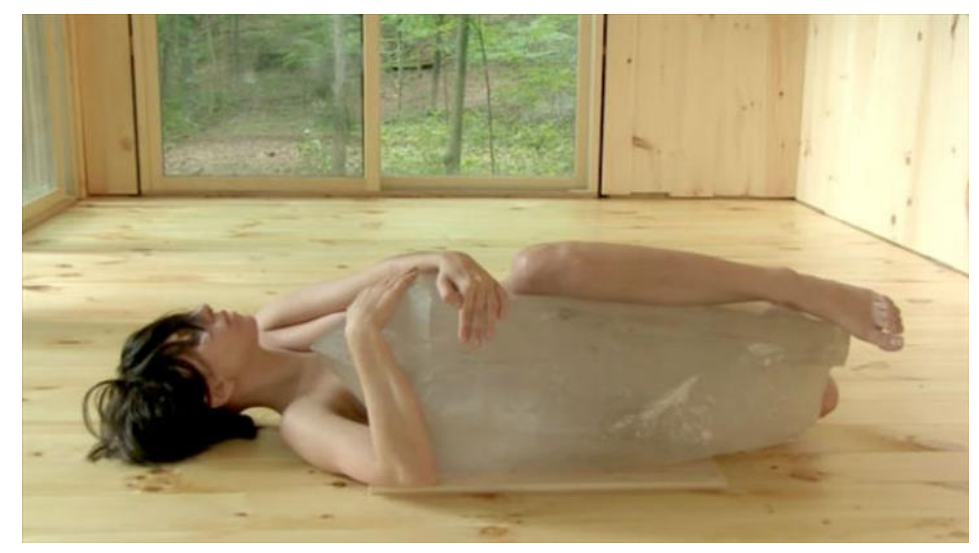

\section{Görsel 10: Abramovic Method, video performance}

\section{Küreselleșen Sanat ve Küratörler}

Küratör, bir sergi (bir müze kapsamında kalıcı veya bir müzede, galeride geçici sergi) yaratarak çok yaratıcı olan bir "kavram" üzerinden serginin tam olarak tanımını ortaya koyarak, organizasyon, sanatçlların ve yapıtların seçimi, söz konusu serginin yayın/ları, sözsel etkinlikleri (konferans, seminer vb.) bu çalışmalarda yer alacak metinleri ve konuşmacıları titizlikle gözetleyerek ve seçerek derinlemesine ele alan kimsedir (Tunçelli, 2014, 71).

Latince curare den türemiş olan kürator kelimesi anlam olarak korumak gözetmek, ilgilenmek gibi anlamlar içermektedir. Küratörler, Roma İmparatorluğu döneminde koruma, gözetme işlevini üstlenen kamu hizmetlileridir. Kendini koruyup, gözetemeyecek durumda olanlara (Reşit olmayanlar, deliler, akıl hastaları, geri zekalılar, sağırlar ve devasız hastalar, savurgan olup malını koruyamayanlar), erkek olması koşuluyla küratör atanıyordu. Daha sonraları muhtemelen ortaçağda kiliseyle ilişkilendirilerek cemaattekilerin ruhlarını koruma ya da iyileştirme sorumluluğunun verildiği kişilere küratör denmiştir. Küratörlük modern zamanlarda sanatla ilişkilendirilmiş, müze koleksiyonundan sorumlu kişiler 
olarak görülmüsstür. Küratör ünvanı sağlam bir kuruma bağlllığı, kalıcı bir koleksiyonun inşasını ve korunmasını ima ediyordu. İkinci dünya savaşından sonraki ylllarda müze küratöründen "sergi yazarı"na bir geçiş oldu yani bugünkü anladığımız anlamda küratörün rolü tarif edilmeye başlandı (Madzoski, 2016, 25-28). Günümüz çağdaş sanatında ise küratörler, kültürel aracı olarak aktif rol oynamaktadırlar. Bourdieu'nun "kültürel aracılar" olarak adlandırdığı kültür, sanat ve eğitim kurumları veya bu alanlarda söz sahibi olan grup ve kişiler, kültürel sınırların çizilmesinde önemli rol oynarlar. Bu grup ve kişilerin neyin sanat eseri olduğu konusundaki görüşleri kurumsal otoritelerce doğru kabul edilir. $\mathrm{Bu}$ yüzden sermaye grupları kültürde söz sahibi olabilmek için kültürel aracılar ile yakından ilişkilidir. Küratörler bazında sıkça sorgulanan şey ise bu yapılanma biçiminin, bazı grupların daha fazla kültürel ve sembolik sermaye biriktirmeleri ve bu grupların kendilerince geçerli olan kültür tanımlarını ve dayatmalarını da mümkün kıldığıdır (Yardımcı, 2014, 127-130).

Kültürün ve sanatın piyasayla iç içe olması küratör faktörünü daha girift ve tartışmalı bir hale getirmektedir. Küratörler, satın alma, değerlendirme, eleştiri yapma, sergilemeye karar verme ve sergi için kavram ve konsept belirleme gibi yetkilerle çă̆daş sanatın ne olduğunu belirleyen dinamiklerdir ama ne derece özerk bir alana sahip olmaları gerektiği hep tartışma konusu olmuştur.

Land art sanatçısı Robert Smithson, küratörlügün kurumsallaştırılmasıyla, yapıtlarının yeni kısıtlamalar sistemine dahil olduğunu söylemiş; 1972'de Documenta 5'e sanat yapıtı yerine kaygı ve eleştirilerini içeren bir metin göndermiştir. Bu metinde muhafız diye adlandırdığı küratörlerce, sanatçıların düzmece kategorilere sığıştırılarak kendi kontrolleri dışında bir hapishaneyi destekler duruma geldiğini söyler ve bunu kültürel kapatma diye ifade eder. Kültürel kapatma ile sanat eserlerinin nötr, etkisiz, güvenli hale dönüștürülerek toplum tarafından tüketilmeye hazır hale getirildiğini 
söyler (Madzoski, 2016, 35-36).

Finansı elinde tutan güçlerin sanatçı, sanat ve küratörler üzerindeki yaptırımının aslında çok belirleyici ve güçlü olduğunu ifade eden Denizhan Özer bu kurumların küratörleri bir aracı olarak düşünmekte ya da kullanmakta olduklarını söylemektedir. Bir diğer küratör Engin Sustam ise, küratörlüğün politik bir durum olduğunu, "Küratör, eseri satmakla yükümlü hale getirilen bir bağlamdan okunduğunda, tamamen bankaların ve sermaye hareketinin aktörü haline gelen siyasal bir komiser gibi hareket etmekte olduğuna ve komiserlik bu anlamıyla ve varlığıyla artık sanat dünyasında kabul edilmektedir." demektedir (Çı̆̆ırlı, 2017).

Küratörler çağdaş sanatı anlamlandırmada etkin rol oynamaktadır. Sanatçıları uluslararası sergilerde buluşturmak, geleneksel galeri ve sergi alanlarından çıkılıp çok çeşitli sergileme yöntemleri belirlemek, sergileri belirli bir konsepte göre düzenlemek gibi yenilikler, küratörlerle gelen yeniliklerdir. Küratörlerin üstlendiği; sanat ortamıyla sanatçıyı buluşturmak, yeni sergi planları yapmak, aracı olmak, günceli takip ederek kavram belirlemek gibi görevler küratörlerin sanat yönetiminde çok etkili bir konumda olduklarını göstermektedir.

\section{Küreselleşme ve Bienaller}

Bienaller, çağdaş sanatın küresel dolaşımını sağlayan, iki yılda bir düzenlenen çok büyük ölçekli uluslararası sergilerdir. Genellikle kendilerine ev sahipliği yapan kentlerle isimlendirilirler. Bir veya daha çok küratörün kavram üzerinden belirlediği konseptte düzenlenirler. İlk bienal olan 1895 Venedik Bienali'nden sonra sanat bienallerinin mega ölçekte uluslararası karma sergi anlamını kazanmaları 1990'lı yıllarda sayılarının çok fazla artmaya başlaması ile eş zamanlıdır. En önemlileri Dokumenta, Venedik, Sâo Paulo, Whitney New York olmak üzere 1970'lerde çağdaş sanat alanında uluslararası ölçekte sadece on tane bulunan bienal veya 
plurienallerin sayısı 2010'larda da yüzü geçmiştir. 1990'lardan itibaren küresel ölçekli sergilerin artışı ile farklı kimlik ve kültürlerden sanatçlların küratörlerce bir araya getirilişi kültürel hareketlilik sağlamıştır. Küratörlerce bu çeşitliliğe göre yeniden yaratılan ideolojik metinler, Batı dışında çoğu ülkenin, kentlerin veya etnik grupların görünürlüğünü arttırma işlevi de görmüștür. Bienaller, Maurice Roche'un küresel yoğunlaşma anı olarak nitelendirdiği mega bir etkinliktir ve küreselleşmeyi kurgulama ve sunma becerisine sahiptir (Bayrak, 2013, 126-127).

Bir bienal aynı zamanda katılımcı ülkeler için bir tanıtım platformudur. Dünyanın dört bir tarafından gelen sanatçlar, kentin çeşitli mekanlarında yapıtlarını sergiler. Çok sayıda ziyaretçi, sanat eserleri, tanıtım filmleri, forumlar, performanslar ve eş zamanlı sergilerle bir bienal haftalarca süren bir sanat festivaline dönüşmektedir. Yardımcı'ya göre festival ve bienallere katılan izleyici, kendisine gösterilen yapıyı okuyarak farklı anlamlar üretme, dayatılan anlama karşı çıkmak olanağına sahiptir. Bu nedenle festival ve bienaller bir yandan tabakalaşmayı kültürel sermaye ekseninde yeniden üretip varolan toplumsal yapıyı olumlarken bir yandan da bu yapıyı dönüştürme potansiyeli taşırlar. (Yardımcı, 2014, 31).

Küreselleşme ile gelişen çok kültürlülük anlayışı ile birlikte 1990'lardan sonra Avrupa dışında birçok merkezde de bienaller düzenlenir. Yardımcı'ya göre bu sergiler genellikle çağdaş sanatı sergilemenin ötesinde farklı siyasal ve ekonomik beklentilerle gerçekleştirilir ve uluslararası kamuoyunun ilgisini çekebilecek yıldız küratörlere teslim edilir. Ancak yine bu nedenle temel aldığı model batı kanunudur (Yardımcı, 2014, 23-25). Böylece bu coğrafya kendi kültürüne batılı gözü ile bakarak küreselleşmeye hizmet etmiş olur.

Avrupa dişında gerçekleştirilen bienallerin en bilineni 1951' den beri Brezilya'da düzenlenen Sao Paulo Bienali'dir. Asya kıtasında Kwangju Bienali, Afrika'da Dakar Bienali, Bantu Bienali, 
Johannesburg Bienali, Avustralya'da Sydney Bienali, Whitney Bienali ve Avrupa'nın çeşitli kentlerinde düzenlenen Manifesta Sergileri çağdaş sanatın önemli etkinlikleri arasında sayılabilir. Julian Stallabrass, bienallerin ilgi odağının batı dışına kayması ile ilgili "O halde bu sergiler, yeni ekonomik ve politik güçlerin kültürel düzeyde geliştirilmesidir ve bu nedenle diğer sergilere ve sanat etkinliklerine göre daha fazla prestij sağlamaktadır" demiștir (Bayrak, 2013, 126127). Bienaller diğer çağdaş sanat fuarlarından farklı olarak ticari bir konumda değildir ancak Bienallerin yarattığı prestij birçok resmi ve özel kuruluşların kültür politikalarını, çağdaş sanatın konumunu belirleyecek kadar güçlü olmaktadır. Dolayısıyla ticari çıkar gözetmeyen bir yapıda olmalarına rağmen diğer çağdaş sanat fuarlarına öncülük etmekte çağdaş sanat piyasasını belirlemektedir.

\section{Sonuç}

Küreselleşme olgusunun yaşamda hissedilmesi küreselleşme süreci olarak tanımlanabilir. 20. yüzyılın sonlarına doğru Berlin Duvarı'nın yıkılışı ve Sovyetler Birliği'nin parçalanışı gibi tüm dünyada gelişen olaylar neticesinde, dünyaya ekonomik olarak tek bir sistemin hakim olduğu düşünülmektedir. Serbest rekabete dayalı bu sistemde çok uluslu şirketler dünyayı kocaman büyük bir pazara dönüştürme süreci içine girmişlerdir. Ülkeler arasındaki sınırlar yok olmaya başlamış; sosyal, siyasi, kültürel alanlarda küreselleşme süreci hızlanmıștır. Bunun yanısıra hızla gelişen teknolojik yenilikler, dijital ve hızlı iletişim toplumlar arasındaki etkileşimi hızlandırmıştır. Küreselleşen dünyada toplumlar ekonomik, kültürel ve siyasi boyutlarda birbirlerinden etkilenerek dönüşüme uğramaktadırlar. $\mathrm{Bu}$ dönüşümün gerçekleşmesinde en etkili yollardan biri de kültürel alandır. Kültürel alan incelendiğinde sanat, reklamcllı ve medya sektörünün bütünleşmiş yapısı karşımızda durmaktadır.

Küreselleşmenin kültürel sonuçları çok kültürlülük (melezleşme) ve homojenleşme, sanatta karşllığını eklektisizm, 
disiplinlerarasılık, yersiz yurtsuzlaşma gibi olgularla bulmuştur. Özellikle, 20. yüzyıl sonunda çok büyük devletlerin parçalanıp birçok farklı kültürün ortaya çıkışı kimlik tartışmalarına yol açarken, çağdaş sanat fuarları ve bienaller farklı kültürlerin sanatlarını ön plana çıkararak sanatın küresel dolaşımını sağlamışlardır. Küresel bazda oluşturulan temalarla bienaller, hem kültürel etkileşimi arttırmakta hem de sorunları sanat yoluyla küreselleştirmektedir. Çok büyük ölçekli sergileme projeleri olan bienaller aynı zamanda kentleri dönüştürücü etkiye sahiptirler. Çok kültürlülük, homojenlik ve kutuplaşma çağdaş sanatın ontolojik yapısını da çok katmanlı her türlü malzemenin kullanılır olduğu bir yapıya dönüştürmüştür. Sanat yapıtları dijital ortamda ve her türlü mekandakurgulanabilmekte böylece kültürel küreselleşme döngüsünü hızlandırmaktadırlar.

Küreselleşmenin kültürel getirileri sonucunda sanat anlayışında, yapısında, sergilenmesinde köklü değişiklikler olmuştur. Küreselleşme sürecinin yoğun olarak yaşandığı 20. yüzyl sonlarından itibaren kültür ve sanatın kendisi bir tüketim ürünü, bir meta olarak piyasaya sürülmüştür. Kültür ve sanatın meta gibi kullanılışı da sanatın ekonomik sistemde başlı başına bir sektör, bir yatırım aracı, bir kültürel aracı olmasına yol açmıştır. Kapitalist şirketler önemli bir faktör olarak kültür ve sanatı kurumsal kimliklerine katmışlardır. Sanat ve sanatçı kimlikleri değişmiş, bir endüstri şirketi gibi markalaşma yoluyla çağdaş sanat pazarında yer bulmaya çalışmışlardır. Çağdaş sanat kendini oluşturan yapısıyla, sanatçısıyla küresel sermayenin cazibe merkezi ve kültürel boyutta kullanacağı önemli bir araçtır ve hiçbir dönemde piyasayla bu kadar yakın olmamıştır. Sanat adeta sanat yönetiminde yer alan birimler arasında kurgulanan bir gösteriye dönüşmüştür. Küratörler, sanat danışmanları, galeri sahipleri, galeri ve müze yöneticileri, koleksiyonerler, sanat kuruluşları ve sanatı kurumsallaştıran büyük şirketler kısacası sanat yönetiminde yer alan birimlerin sanatın ne olduğu, nasıl yapılması gerektiği konusunda karar verici merci olmaları sanatın ve sanatçının özgürlügünü kısıtlamaktadır. 
Sanatçılar ayakta kalabilmek adına sanat piyasasının beklentilerine göre davranmayı seçmektedir ama sanatın aurası sermaye bağımlılığını sanat lehine çevirecek kadar büyüktür ki birçok sanatçı bireysel olarak veya sanat inisiyatifleri ile kendilerine özgürlük alanı yaratmaya çalışmaktadırlar. Çağdaş sanatın yerel ve tikel olanı, etnik kültürleri öne çıkaran tavrı da bazen sanatçılar için kendi sanatlarını çağdaş sanat piyasalarında icra edebilmek için firsat olabilmektedir ama küreselleşen sanat bir yandan bu duruma olanak tanırken diğer taraftan bu tutum kültürler arası kutuplaşmayı belirginleştirmektedir. Çağdaş sanat kutuplaşmaya ve ayrımcılığa hizmet etmiş olmaktadır. Aynı zamanda yerel, etnik sanatlar ötekileştirilerek, güçlü olanın manipülasyonuna uğramaktadır. Çalışmada görülmüştür ki çağdaş sanat küreselleşmenin önemli bir dinamiğidir. Çağdaş sanatın aurası kültürel küreselleşmenin negatif etkilerini olumlu etkileri ile sanat lehine çevirecek kadar büyük olmalıdır.

\section{Kaynakça}

Aktaş, İsmail-Deliklitaş, Murat. "Şoray'ın Resmine 200 bin TL". Hürriyet. 24 Mart 2010. Erişim: 1 Mayıs 2018. http://www.hurriyet.com.tr/gundem/sorayin-resmine-200bin-tl-14204051

Antmen, Ahu. "Ve karşınızda: Haluk Akakçe!”. Radikal. 31 Mart 2010. Erişim: 5 Mayis 2018.

http://www.radikal.com.tr/yazarlar/ahu-antmen/vekarsinizda-haluk-akakce-988721/

Artun, Ali. Çağdaş Sanat ve Kültüralizm. çev. Tuncay Birkan-Nursu Örge-Elçin Gen. İstanbul: İletişim Yayınları, 2015.

Battinelli, Philippe. "Ausfegen 1972". New Media Encyclopedia. t.y. Erişim:3 Haziran 2018. http://www.newmedia-art.org/cgibin/show-oeu.asp?ID=150000000034295\&lg=GBR 
Baransel, Zeynep. "Umumi Mahremiyet-Bir Tracey Emin Portresi". E-Skop Dergi (2 Ekim 2011). Erişim: 20 Nisan 2018. http://www.e-skop.com/skopbulten/umumi-mahremiyet--bir-tracey-emin-portresi/409

Bayrak, Bengisu. "Çağdaş Sanatın Ticarileşmesine Küreselleşmenin Etkileri". Beykent Üniversitesi Sosyal Bilimler Dergisi 6/1 (Ocak 2013): 123-137.

Çelik, Mehmet Yunus. "Boyutları ve Farklı Algılarıyla Küreselleşme”. Dumlupınar Üniversitesi Sosyal Bilimler Dergisi 32/2 (Nisan 2012): 57-73.

Çı̆̆ırlı, Eda. "Çağdaş Sanat Ortamında Küratör Olmak". İzlekler Sanat ve Kültür Dergisi (27 Ekim 2017). Erişim: 5 Mayıs 2018. http://izlekler.com/cagdas-sanat-ortaminda-kuratorun-rolueda-cigirli/

Dellaloğlu, F. Besim. Frankfurt Okulunda Sanat ve Toplum. İstanbul: Say Yayınları, 2018.

Erdoğan, M. "Küresel Çağda Çağdaş Sanat ve Küresel Sanat Pazarı. Anadolu Üniversitesi". Sosyal Bilimler Dergisi 15/ 1 (2015): 75-98. http://dx.doi.org/10.18037/ausbd.98486

Ersoy, Ersan. "Tarihsel Kapitalizmden Güncel Kapitalizme Küreselleşme”. Doğu Anadolu Bölgesi Araştırmaları 1/1 (2008): 143-153. http://web.firat.edu.tr/daum/docs/71/24\%20Tarihsel\%20K apitalizm-Ersan\%20ERSOY-ödendi\%2011syf-143-153.doc

Eşkinat, Rana. “McLuhan’ın Küreselleşme Teorisine Katkıda Bulunan Öncü Görüşleri”. Kurgu Anadolu Üniversitesi İletişim Bilimleri Fakültesi Uluslararası Hakemli İletişim Dergisi 15/15 (Ocak 1998): 33-43. 
Günsoy, Bülent. Küreselleşmenin Ölçülmesinde Sistematik Yaklaşımlar; Karşılaştırmalı Bir İnceleme. Ankara: Kırlangıç Yayınevi, 2006.

Harris, Richard G. "Globalization, Trade, and Income". The Canadian Journal of Economics 26/4 (Kasım 1993): 755-776. https://www.jstor.org/stable/135819 DOI: 10.2307/135819

Holton, Robert. "Küreselleşmenin Kültürel Sonuçları". çev. Kasım Karaman. Sosyoloji Konferansları. 0/47 No:47 (Ağustos 2013): 59-75.

Kuspit, Donald. Sanatın Sonu. çev. Yasemin Tezgiden. İstanbul: Metis Yayınları, 2006.

Madzoski, Vesna. Küratörlük; Koruma ve Kapatmanın Diyalektiği. çev. Mine.Haydaroğlu. İstanbul: Koç Üniversitesi Yayınları, 2016.

Museum of Fine Arts. "Exhibition; Candice Breitz: Love Story". Erişim: $\quad 20 \quad$ Nisan 2018. https://www.mfa.org/exhibitions/candice-breitz-love-story

Onan, Coşkun Berna. Çağdaş Sanat Öğretiminde Disiplinlerarasıllı: Fenomeloji Çalışması. Doktora Tezi, Eskişehir Anadolu Üniversitesi Eğitim Bilimleri Enstitüsü, 2016.

Robertson, Roland. Globalization: Social Theory and Global Culture. London: Sage, 2000. http://dx.doi.org/10.4135/9781446280447

Sanatatak. "Marina Abramovic Enstitüsü Hayal Oldu". 17 Ekim 2017. Erişim: 8 Mayıs 2018. http://www.sanatatak.com/view/marina-abramovicenstitusu-hayal-oldu 
Thompson, Don. Sanat Mezat. çev. RenanAkman. İstanbul: İletişim Yayınları, 2012.

Tunçelli, Oylum. Günümüz Sanatında Sanat Eseri ve Değerinin Değişkenleri; Andreas Gursky örneği. Sanatta Yeterlilik tezi, T.C. Kocaeli Üniversitesi Sosyal Bilimler Enstitüsü, 2014.

Ozgur, Ede. "Tracey Emin 'Everyone I Have Slept With 1963-1995”. 8 Nisan 2014. Erişim: 10 Mayıs 2018. https://edeozgur.wordpress.com/2014/04/08/tracey-emineveryone-i-have-slept-with-1963-1995/

Yardımcı, Sibel. İstanbul'da Bienal. İstanbul: İletişim Yayınları, 2014.

\section{Görseller Kaynakça}

Görsel 1- "The Golden Buddha”. Erişim $10 \quad 102018$. https://www.artbasel.com/catalog/artwork/15049/NamJune-Paik-Golden-Buddha

Görsel 2- "Ausfegen". Erişim: $506 \quad 2018$. https://www.pinterest.co.uk/pin/299911656421244255/?lp =true

Görsel 3- "New Hoover Convertibles". Erişim: 18052018. http://collection.whitney.org/object/7399

Görsel 4- "Eveyone I Have Ever Slept with 1963-1995". Erişim: 18 05 2018.

https://edeozgur.wordpress.com/2014/04/08/tracey-emineveryone-i-have-slept-with-1963-1995/

Görsel 5- "My Bed". Erişim: $20 \quad 05 \quad 2018$. http://www.milliyetsanat.com/haberler/plastik-sanatlar/yatagim---my-bed----tracey-emin/546 
Görsel 6-7 "Love Story". Erişim: $21 \quad 05 \quad 2018$. http://www.candicebreitz.net

Görsel 8- "The Flower Thrower". Erişim: $8 \quad 102018$. https://www.theartstory.org/artist-banksy-artworks.htm

Görsel 9- "The Physical İmpossibility of Death in The Mind of Someone Living". Erişim: $22 \quad 052018$. http://www.damienhirst.com/the-physical-impossibility-of

Görsel 10- "Abramovic Method". Erişim $12 \quad 10 \quad 2018$. http://www.arttv.com.tr/sanatcilar/diger/abramovicmetodu-ile-lady-gaga 